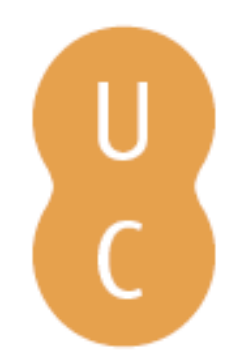

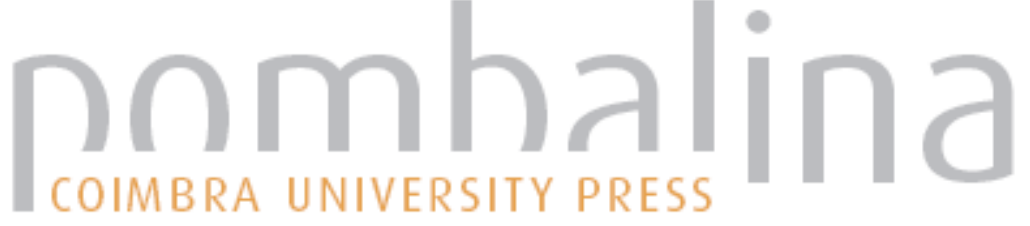

\section{Fire seasons in Portugal: the role of weather and climate}

Autor(es): $\quad$ Amraoui, Malik; Parente, Joana; Pereira, Mário G.

Publicado por: Imprensa da Universidade de Coimbra

URL

persistente: URI:http://hdl.handle.net/10316.2/44568

DOI: $\quad$ DOI:https://doi.org/10.14195/978-989-26-16-506_51

Accessed : $\quad$ 26-Apr-2023 12:17:04

A navegação consulta e descarregamento dos títulos inseridos nas Bibliotecas Digitais UC Digitalis, UC Pombalina e UC Impactum, pressupõem a aceitação plena e sem reservas dos Termos e Condições de Uso destas Bibliotecas Digitais, disponíveis em https://digitalis.uc.pt/pt-pt/termos.

Conforme exposto nos referidos Termos e Condições de Uso, o descarregamento de títulos de acesso restrito requer uma licença válida de autorização devendo o utilizador aceder ao(s) documento(s) a partir de um endereço de IP da instituição detentora da supramencionada licença.

Ao utilizador é apenas permitido o descarregamento para uso pessoal, pelo que o emprego do(s) título(s) descarregado(s) para outro fim, designadamente comercial, carece de autorização do respetivo autor ou editor da obra.

Na medida em que todas as obras da UC Digitalis se encontram protegidas pelo Código do Direito de Autor e Direitos Conexos e demais legislação aplicável, toda a cópia, parcial ou total, deste documento, nos casos em que é legalmente admitida, deverá conter ou fazer-se acompanhar por este aviso. 


\section{ADVANCES IN}

\section{FOREST FIRE RESEARCH}

\section{8}

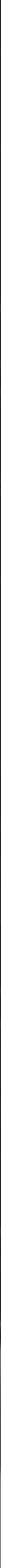




\title{
Fire seasons in Portugal: the role of weather and climate
}

\author{
Malik Amraoui ${ }^{1 *}$; Joana Parente ${ }^{1}$; Mário G. Pereira ${ }^{1,2}$ \\ ${ }^{1}$ Centro de Investigação e Tecnologias Agroambientais e Biológicas, Universidade de Trás-os- \\ Montes e Alto Douro, Quinta de Prados, 5000-801 Vila Real, Portugal, \{malik@utad.pt*, \\ joanaparente@utad.pt,gpereira@utad.pt\} \\ ${ }^{2}$ Instituto Dom Luiz, Faculdade de Ciências da Universidade de Lisboa, Lisboa, Portugal, \\ \{gpereira@utad.pt\}
}

\begin{abstract}
Forest fires (FFs) are critical elements of Earth system at the global, regional and local scales and, independently of their causes may have a high environmental, social, economic and climatological effects as well as cause loss of lives and injured people. Weather and climate control, directly and indirectly, most of the aspects of FFs. This study aims to identify: (i) the temporal variability of FFs, with special attention to the differences between the spring and summer fire seasons; and, (ii) the weather conditions during the days and months of higher and lower fire incidence. The fire database used is the Portuguese Rural Fire Dataset that comprises relevant information about each fire event such as: ignition date, fire duration, location ignition and total burnt area (BA). The meteorological dataset used is the ERA-Interim which covers the climatological 35-years period (1980 - 2014) and consists of daily fields at 12 UTC, with a spatial resolution of $0.125^{\circ} \times 0.125^{\circ}$ latitude/longitude grid, over a spatial domain $\left(10^{\circ} \mathrm{W}-6^{\circ} \mathrm{E}, 36.5^{\circ} \mathrm{N}-42.5^{\circ} \mathrm{N}\right)$ centred in Portugal. The role played by the meteorological conditions over a given region is assessed by analysing the associated patterns of thermo-hydro-dynamical fields at different atmospheric levels. Analysed patterns are anomaly composites, consisting of arithmetic means (performed over all days associated with very high number of FFs) of daily departures of 12 UTC meteorological fields from the respective average for that day over the reference period (1980 - 2014). Temporal variability of fires (number of forest fires, NFF) in Portugal unveil two fire seasons: (i) the first one, during winter-spring with highest activity in March (part of the non-critical period, NCP); and, (ii) the second, in summer with pronounced peak in July and August (during the critical period, CP). Atmospheric thermodynamic and circulation patterns confirm the existence of anomalous conditions observed over the affected areas, on daily and monthly scales. This atmospheric circulation is characterized by predominant easterlies crossing that advect continental air into the sub-region. During summer, the circulation is characterized by a predominant hot and dry flow from continental Europe and north Africa, contributing to values of air temperature (relative humidity) well above (below) average. During winter, the extremely low values of relative humidity are the most noticeable feature, which result from the anomalous Eastward circulation over the cold and dry Western Europe. The findings of this study will contribute to a better fire prevention, firefighting and crisis management.
\end{abstract}

Keywords: Temporal variability; Fire Season; Forest Fires; Weather conditions; Portugal

\section{Introduction}

The natural vegetation in most of Europe is essentially forest and woodland from the Mediterranean through the deciduous forests of Central and Western Europe to the boreal forests in Fennoscandia (Bengtsson et al., 2000). Over the last 20 years, the forested area expanded in all European regions and has gained 0.8 million hectares each year (Forest Europe, 2011) except in southern European countries, where fires burn large areas every year (Schmuck et al, 2012).

Forest fires (FFs) are critical elements of Earth system at the global, regional and local scales and, independently of their causes (lightning/natural, negligent or intentional) may have a high environmental, social, economic and climatological effects as well as cause loss of lives and injured 
people. (Amraoui et al. 2015; Parente et al. 2016). Fires affect a larger area over a wider variety of biomes across the globe than any other natural disturbance to land-based eco-systems (Ichoku et al., 2008). The Mediterranean region, including Portugal, occupies a prominent position, given the occurrence of devastating fires that burn hundreds of thousands of hectares of forest, scrublands and grasslands every year (Barbosa et al., 2007). In this region, fire ignition is strongly conditioned by human behaviour and socioeconomic activities (Costa et al., 2010) but natural factors like the morphology of the landscape, land use, land cover, and meteorological conditions have also to be taken into account (Amraoui et al., 2013, Parente et al., 2018a).

Despite its smaller land area in comparison with other Mediterranean countries, Portugal is the European country with highest total number of FFs and the second largest total BA (San-MiguelAyanz et al., 2016). In Portugal, fire incidence (number of FFs and BA) presents a high spatial and temporal variabilities, with weather and climate conditions as the main drivers of the temporal distribution (Pereira et al., 2005; Parente et al. 2017) having a profound influence at all stages of biomass burning from ignition, spread and behaviour up to severity and effects. In this context, the aims of this study are to identify: (i) the temporal variability of FFs, namely the intra-annual variability, (ii) with special attention to the differences between the spring and summer fire seasons; and, (iii) the weather conditions during the periods of higher and lower fire incidence.

\section{Data and Methodology}

\subsection{Study Area}

Mainland of Portugal is located on the south-western coast of the Iberian Peninsula just at a few hundred kilometres of North Africa with a land area of about $90,000 \mathrm{~km}^{2}$. The Tagus River divides the territory into two regions with similar area but very different in terms of several biophysical and human drivers (Parente et al. 2016), which combined with the occurrence of extreme hot spells and drought periods promote the occurrence and the variability of FFs.

\subsection{Fire dataset}

Information about the FFs was obtained from the Portuguese Rural Fire Dataset (PRFD) originally available in Portuguese Institute for the Conservation of Nature and Forests portal. PRFD comprises relevant information about each fire event such as: ignition date, fire duration, location ignition and total BA. This study relied on the recent 14-years period (2001 - 2014) and based on fires having burnt area greater or equal than 0.1 ha for homogeneity reasons.

\subsection{Meteorological dataset}

The meteorological dataset used in this study corresponds to the ERA-Interim which covers the 35years climatological period $(1980-2014)$ and consists of multiple daily horizontal fields of the low and the medium atmosphere, at $12 \mathrm{UTC}$, with a spatial resolution of $0.125^{\circ} \times 0.125^{\circ}$ latitude/longitude grid, over a spatial domain $\left(10^{\circ} \mathrm{W}-6^{\circ} \mathrm{E}, 36.5^{\circ} \mathrm{N}-42.5^{\circ} \mathrm{N}\right)$ centred in Portugal for a set of the following variables: (i) mean sea level pressure, MSLP; (ii) air temperature at $2 \mathrm{~m}$ height, T2m; (iii) wind speed and direction at $10 \mathrm{~m}, \mathrm{~W} 10 \mathrm{~m}$; (iv) relative air humidity at $850 \mathrm{hPa}, \mathrm{RH} 850$; and, (v) geopotential height at $500 \mathrm{hPa}, \mathrm{Z500}$. Detailed additional information about the ERA-Interim product may be found in Dee et al. (2011).

\subsection{Methodology}

The role played by the meteorological conditions, during periods of high and low fire activity, over mainland Portugal were assessed by analysing the associated patterns of meteorological fields at different atmospheric levels, similar to what was done in previous works such as Pereira et al. (2005), Amraoui et al (2013 and 2015) and Trigo et al., (2013). Analysed patterns are composites and anomaly composites, consisting of arithmetic means (performed for a subset of days of very high/low number 
of FFs) of daily values, in the former case, and departures of 12 UTC meteorological fields from the respective average for that day over the reference period of $1980-2014$, in the latter case.

\section{Results}

\subsection{Temporal distribution of fires}

During the 14-year study period, a grand total of 145,616 FFs were observed over the study region and corresponding to $1.8 \mathrm{Mha}$ of BA, approximately. The temporal distribution of FFs reveals high inter-annual variability (Figure 1, upper panel), with the years of 2001, 2002, 2005, 2009 and 2011 presenting above-average number of FFs. In particular, the years of 2005 and 2001, correspond to the years with greater number of FFs, accounting of about 16,600 (11.4\% of total) and 15,000 (10.3\% of total), respectively. In contrast, 2014 and 2008 represent the years of very weak fire activity with only 3,100 (2.2\% of total) and 5,900 (4.1\% of total), respectively.

Regarding the intra-annual variability (Figure 1, lower panel), there is a prominent annual cycle of fire activity, showing two fire seasons in Portugal. The first one begins in late spring and lasts until early autumn (June to October), totalizing about $75 \%$ of annual FFs, with pronounced peak in AugustSeptember and corresponding to the critical period. The second season, counting about $20 \%$ of annual FFs, is observed in winter and early spring (February to April) with a less prominent peak in March and corresponding to the non-critical period. The remaining 5\% of annual FFs are registered during the months of November, December and January, corresponding to the period with lowest fire activity.

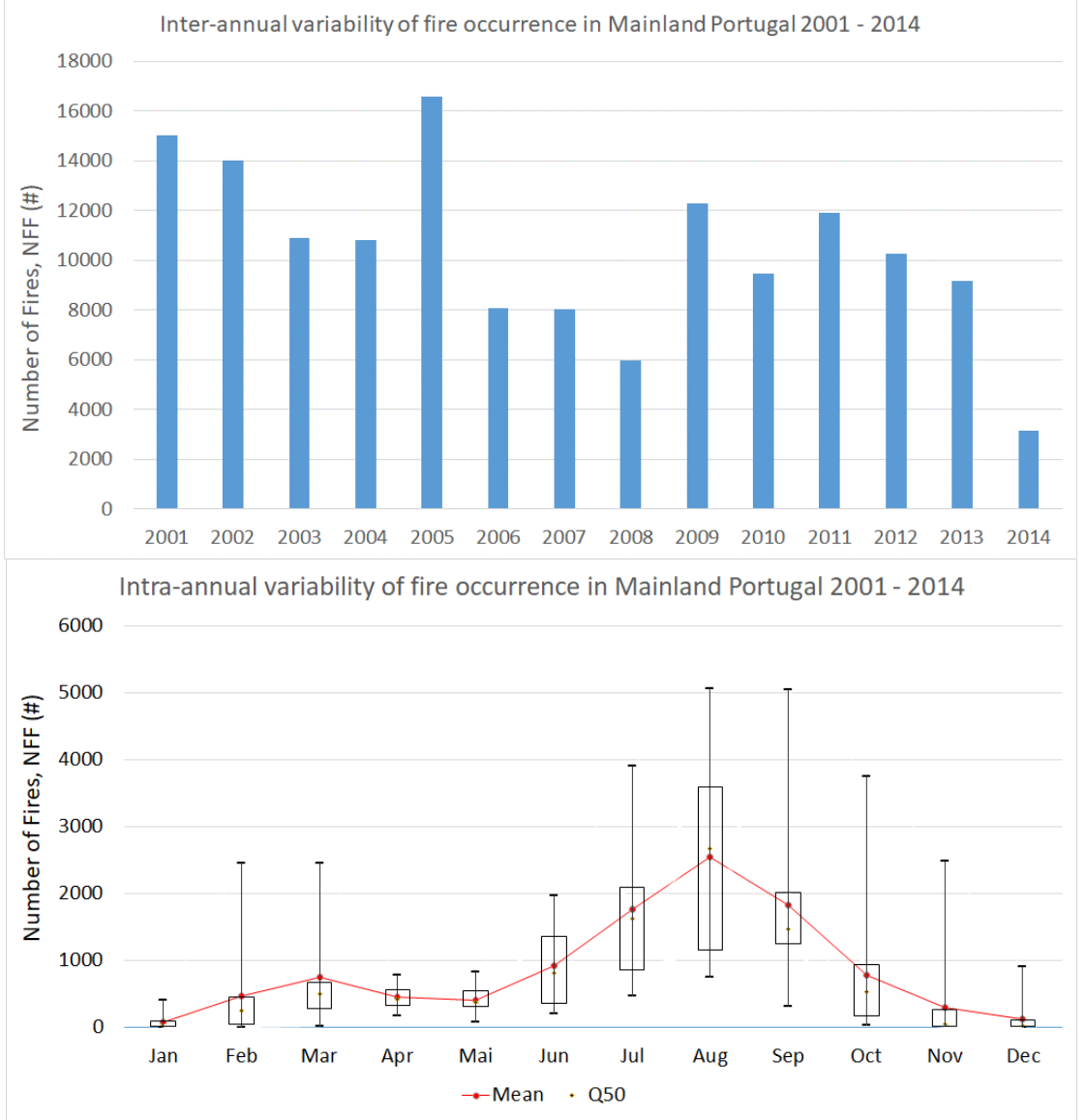

Figure 1 - Inter-annual (upper panel) and intra-annual (lower panel) variability of fire occurrence in mainland Portugal. The used data in the figure refers to all fires, with BA greater than 0.1 ha, observed in the country during the 2001-2014 study period. In the lower panel and for the monthly FFs, the black (red) dots represent the median (mean) value, the lower (upper) box limits represent the first (third) quartile and the lower (upper) whisker represents the minimum (maximum) value.

Advances in Forest Fire Research 2018 - Page 474 


\subsection{Atmospheric conditions associated with high fire activity}

Results obtained in the previous section suggest performing an assessment of the role played by meteorological conditions on the onset and spreading of fire events in mainland Portugal, during the two fire seasons. The weather conditions during periods with very low fire activity were also analysed. Anomaly composites fields of meteorological variables for periods of very high and very low fire activity in the region and season will be presented. Each plot includes results obtained for more than one meteorological field and for each case, two figures of anomalies are presented. The first one respecting to meteorological fields near the surface (T2m, MSLP and W10m) and the other at $500 \mathrm{hPa}$ and $850 \mathrm{hPa}$ levels (Z500 and RH850).

The vast majority of burned area in Portugal is due to a reduced number of extreme events that occur during a short period of time and are associated with several atmospheric processes interacting at different temporal and spatial scales. In general, when high fire incidence is registered, atmospheric thermodynamic and circulation patterns confirm the existence of anomalous conditions observed over the affected areas, on daily and even monthly scales.

\subsubsection{High fire activity during winter}

When FFs occur in the winter-spring season (e.g. Figure 2), the atmospheric surface circulation over Portugal is generally characterized by predominant easterlies that advect continental (cold and very dry) air into the region (Figure 2, lower panel), causing extremely low values of RH850 (Figure 2 , upper panel). These patterns are a usually a consequence of a strong omega blocking configuration (not shown) located west of Europe, enhancing the effect of the anticyclone over Western and Northern Iberia (Amraoui et al., 2015).
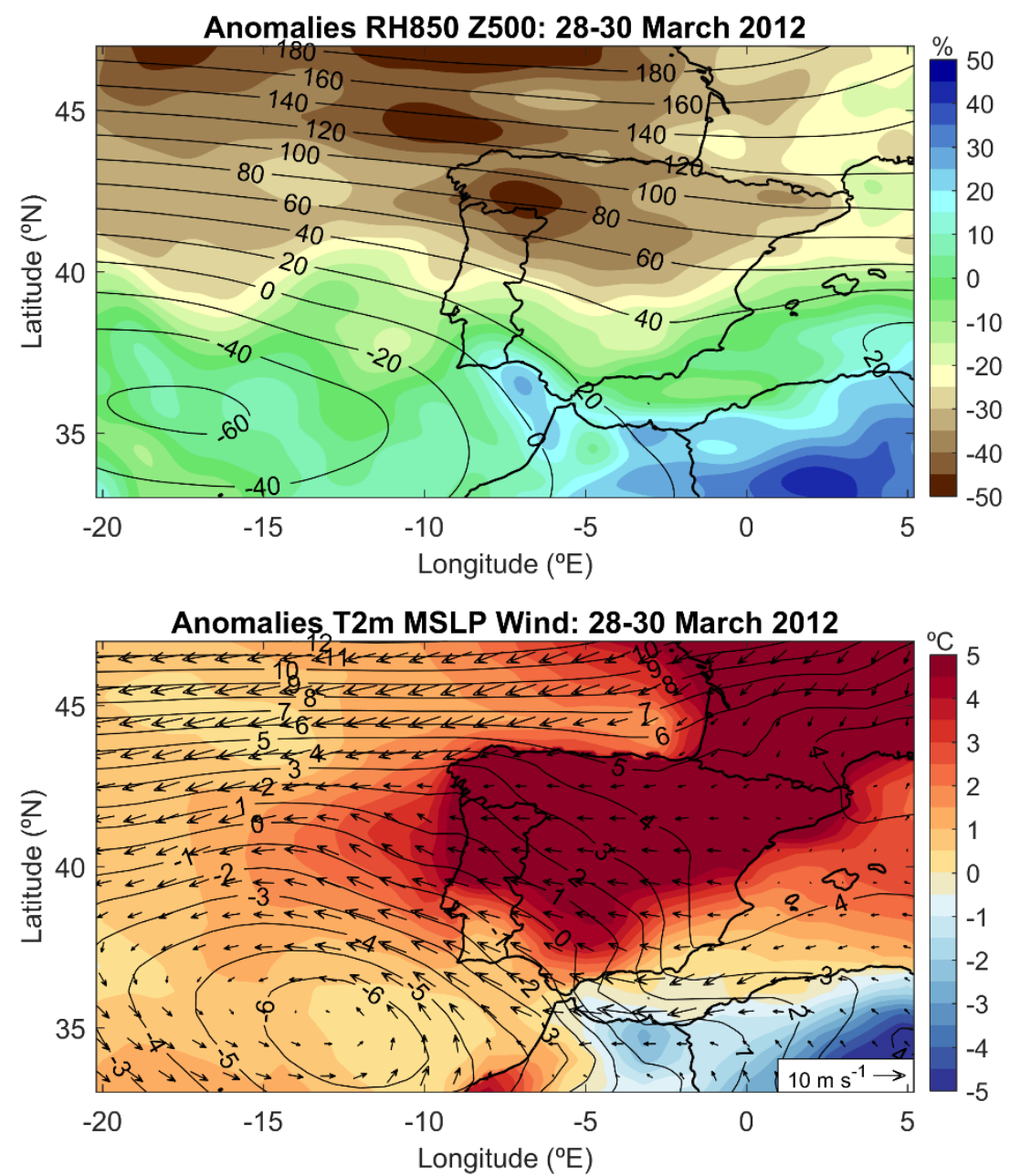

Figure 2 - Anomaly composites of relative air humidity $(\%)$ at $850 \mathrm{hPa}$ level (RH850) and geopotential height (gpm) at $500 \mathrm{hPa}$ (Z500) (upper panel) as well as of air temperature $\left({ }^{\circ} \mathrm{C}\right)$ at $2 \mathrm{~m}(\mathrm{~T} 2 \mathrm{~m})$, mean sea level pressure (hPa) (MSLP), wind speed $\left(\mathrm{m} \cdot \mathrm{s}^{-1}\right)$ and direction at $10 \mathrm{~m}$ (W10m) (lower panel) over Continental Portugal for the period between 28 and 30 of March 2012. 
The anomalous circulation patterns at the $500 \mathrm{hPa}$ level during periods of high fire activity in the winter-spring season are dominated by positive departures of Z500 reaching the impressive value of about $180 \mathrm{gpm}$ (Figure 2, upper panel) over the British Isles. On the other hand, anomalies of meteorological parameters show higher values of T2m than normal over all Iberia and south of France (Figure 2, lower panel) and very low values of RH850, reaching the impressive value of $-50 \%$ in some of the cases (Figure 2, upper panel).

\subsection{High fire activity during summer}

During the summer-autumn season (e.g. Figure 3), the circulation pattern leads to strong NorthEastern, from continental Europe, and South-Eastern, from Northern Africa, advections of continental dry and very warm air over mainland Portugal, contributing to values of air temperature (relative humidity) well above (below) average. This atmospheric circulation is the result from the amplification of the anticyclone of Azores, extending from the Atlantic to Central Europe and by a sub-Saharan thermal low centred at South Algeria (not shown).
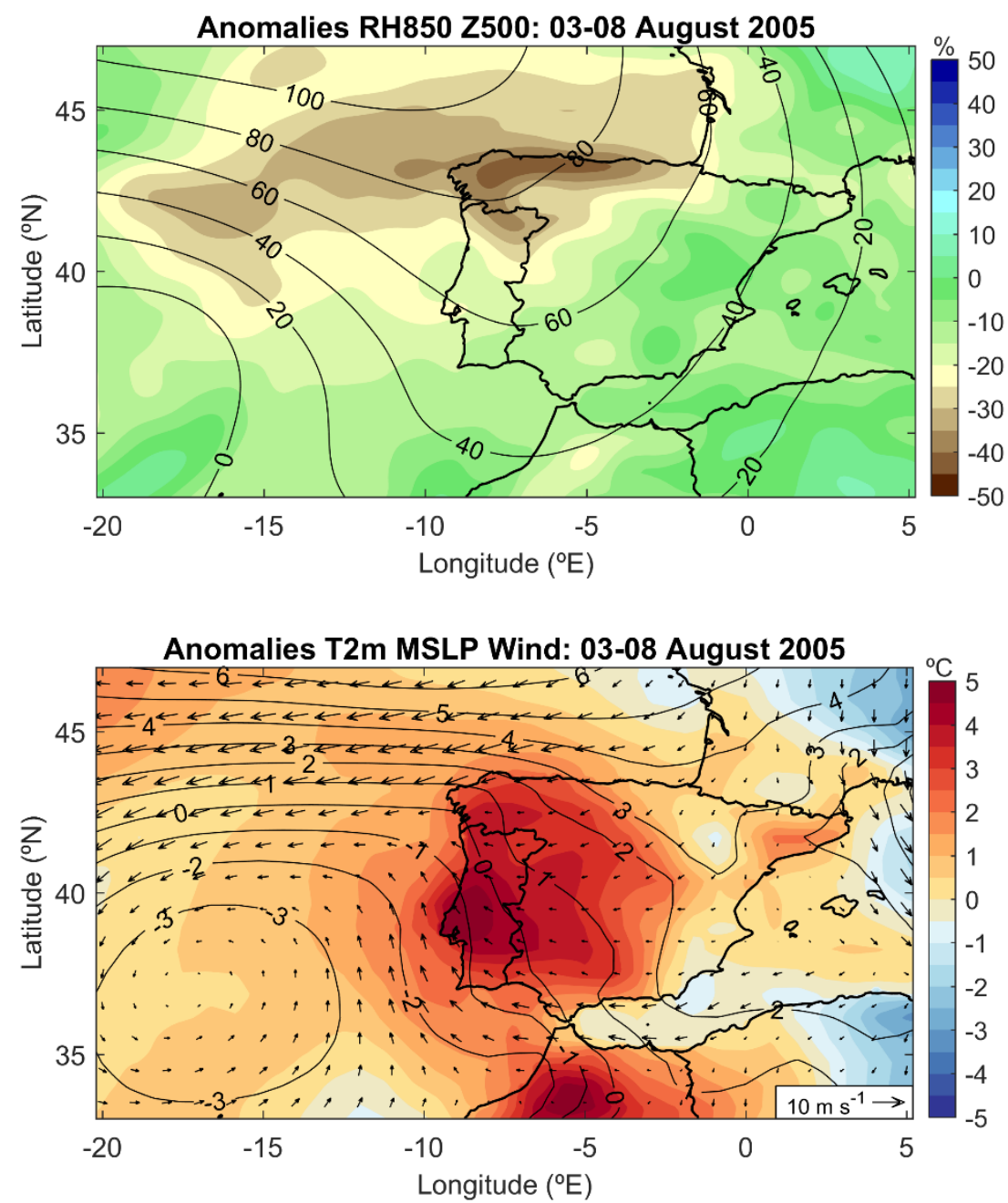

Figure 3 - Anomaly composites of air relative humidity (\%) at 850 hPa level (RH850) and geopotential height (gpm) at $500 \mathrm{hPa}(\mathrm{Z500})$ (left panel) as well as of air temperature $\left({ }^{\circ} \mathrm{C}\right)$ at $2 \mathrm{~m}(\mathrm{~T} 2 \mathrm{~m})$, mean sea level pressure (hPa) (MSLP), wind speed $(\mathrm{m} \cdot \mathrm{s}-1)$ and direction at $10 \mathrm{~m}(\mathrm{~W} 10 \mathrm{~m})$ (right panel) over Continental Portugal for the period between 03 and 08 of August 2005.

The atmospheric flow at $500 \mathrm{hPa}$ (not shown) generally presents the synoptic baroclinic activity with a pronounced ridge with axes in the Southeast to Northwest direction over the Atlantic Ocean and West of Iberia, forcing warmer and drier air mass into the region. The case presented in figure 3 
corresponds to the Arouca extreme fire event that occurred between 03 and 08 of August 2005. In the above-mentioned case, the 500 level composite anomaly patterns exhibit positive departures of 80 gpm (Figure 3, upper panel) and, consequently, enhancing the subsidence of air into the region, reinforcing the increase of air temperature. At surface level, anomalies of meteorological parameters present low values of relative humidity (Figure 3, upper panel) and very hot air temperature (Figure 3, lower panel).

\subsubsection{Low fire activity}

On the other hand, when low fire incidence is observed (e.g. Figure 4) the atmospheric circulation is mostly dominated by western advection of mild wet air from the Atlantic over mainland Portugal, resulting in positive departures and very high values of RH850.
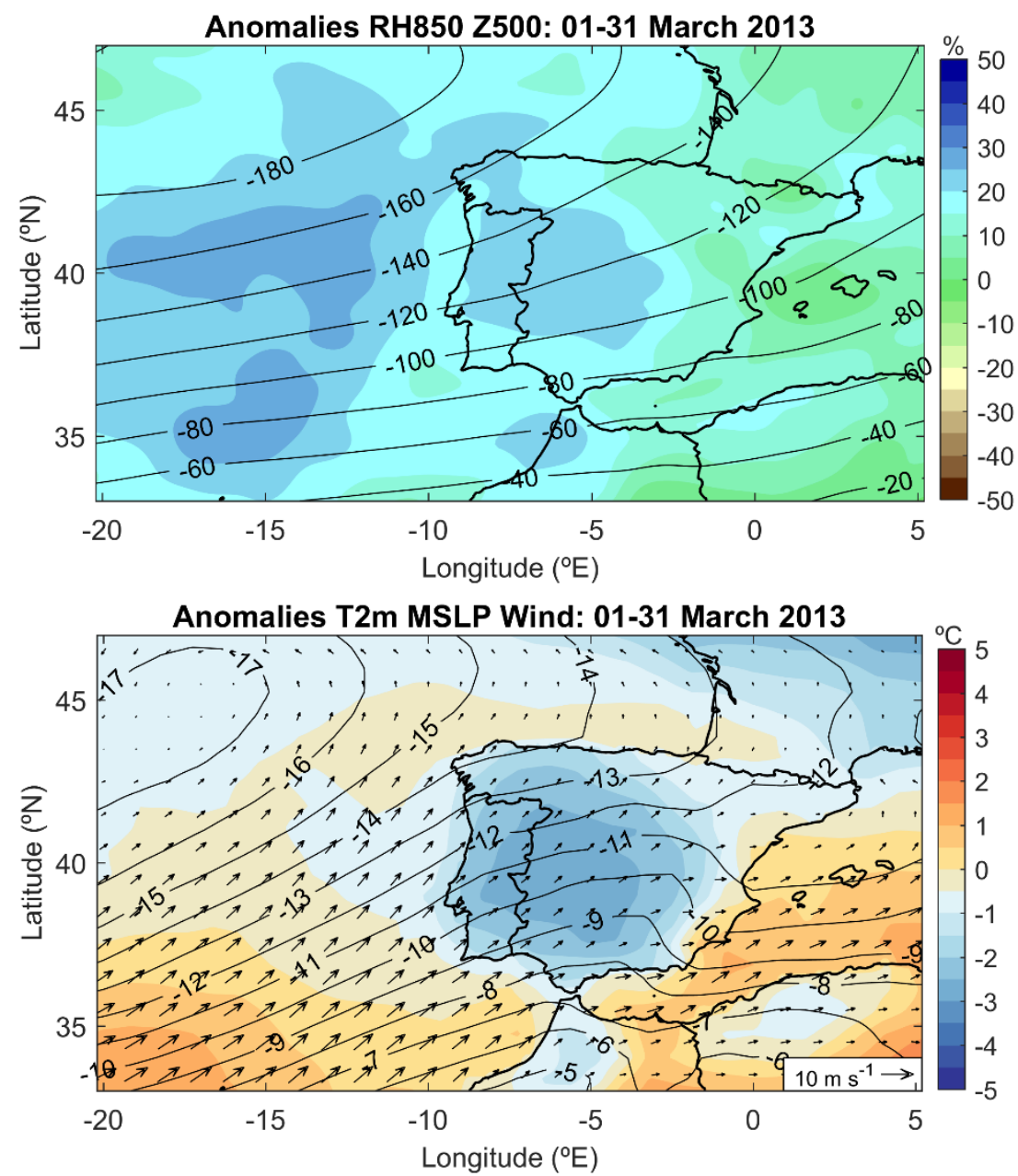

Figure 4 - Anomaly composites of relative air humidity (\%) at 850 hPa level (RH850) and geopotential height (gpm) at $500 \mathrm{hPa}$ (Z500) (left panel) as well as of air temperature $\left({ }^{\circ} \mathrm{C}\right)$ at $2 \mathrm{~m}(\mathrm{~T} 2 \mathrm{~m})$, mean sea level pressure (hPa) (MSLP), wind speed $\left(\mathrm{m} \cdot \mathrm{s}^{-1}\right)$ and direction at $10 \mathrm{~m}(\mathrm{~W} 10 \mathrm{~m})$ (right panel) over Continental Portugal for March of 2013

The case presented in figure 4 corresponds to March 2013 where a few number of fires was recorded. The atmospheric conditions in the region during the referred month are associated with cyclonic configurations located over the Atlantic Ocean, west, northwest or southwest of the Iberian Peninsula favouring precipitation over Portugal through strong advection of maritime air masses.

\section{Conclusions}

The intra- and inter-annual variability of fire activity in Mainland Portugal is strongly associated with the type of climate (Costa et al., 2010) and the occurrence of extreme weather conditions (Pereira 
et al., 2005; Amraoui et al., 2015). However, there is not a cause-effect relationship between atmospheric conditions and fire activity in the sense that fire ignition in Portugal, in particular, and Mediterranean region, in general, is mainly due to human activities (San-Miguel-Ayanz et al., 2013). The temperate type of the Mediterranean basin climate, characterized by wet and mild winters, favour the growth of vegetation, followed by warm and dry weather during summer, promote severe vegetation hydric and thermal stress (Pereira et al., 2013). In Portugal, and during the summer season, the regional heatwaves are very frequent and highly correlated with the occurrence of the most devastating fires in Portugal (Parente et al., 2018b). In addition, recent studies have shown that the occurrence of major droughts in southern Europe during the preceding winter and spring seasons may enlarge the amplitude of heatwaves in the following summer, which in turn, should be viewed as a primary factor of fire danger in this region because of their influence on fuel availability and vegetation hydric and thermal stress.

The vast majority of modelling studies agrees in that the Mediterranean will become hotter and drier in the future favouring the increase in frequency and amplitude of heatwaves over the Mediterranean basin (Fischer and Schär, 2010; Parente et al., 2018b) and, consequently, the intensification of catastrophic fire events and the resulting very high annual burnt area (Trigo et al., 2006, Amraoui et al, 2013). In this sense, knowing the spatial configuration of the meteorological fields associated with highest fire activity is of paramount importance for the planning of fire prevention activities and management of fire suppression resources (Amraoui et al. 2015). In this sense, the findings of this study will contribute to a better fire prevention, firefighting and crisis management.

\section{Acknowledgements}

This work was funded by the R\&D Project FIREXTR - Prevent and prepare society for extreme fire events: the challenge of seeing the "forest" and not just the "trees", with reference POCI-01-0145FEDER-016702 and PTDC/ATP-GEO/0462/2014, financed by the European Regional Development Fund (ERDF) through COMPETE 2020 - Operational Program for Competitiveness and Internationalization (POCI) and by the Foundation for Science and Technology (FCT). The study was also supported by Project Interact - Integrative Research in Environment, Agro-Chain and Technology, NORTE-01-0145-FEDER-000017, research line BEST, co-funded by FEDER/NORTE 2020.

\section{References}

Amraoui, M., Liberato, M.L.R., Calado, T.J., DaCamara, C.C., Pinto Coelho, L., Trigo, R.M., Gouveia, C.M., 2013. Fire activity over Mediterranean Europe based on information from Meteosat-8. For. Ecol. Manag. 294, 62-75.

Amraoui M, Pereira MG, DaCamara CC, Calado TJ, 2015. Atmospheric conditions associated with extreme fire activity in the Western Mediterranean region. Sci Total Environ 524:32-39.

Barbosa, P., Amatulli, G., Boca, R., Camia, A., Kucera, J., Libertà, G., San-Miguel Ayanz, J., Schmuck, G., Schulte, E., Dierks, H.-H., 2007. Forest fires in Europe 2006. EUR 22931 EN Joint Research Centre - Institute for Environment and Sustainability. EUR, Scientific and Technical Research seriesOffice for Official Publications of the European Communities, Luxembourg

Bengtsson J, Nilsson SG, Franc A, Menozzi P, 2000. Biodiversity, disturbances, ecosystem function and management of European forests. Forest Ecology and Management 132: 39-50

Costa, L., Thonicke, K., Poulter, B., Badek, F.W., 2010. Sensitivity of Portuguese forest fires to climatic, human, and landscape variables: subnational differences between fire drivers in extreme fire years and decadal averages. Reg. Environ. Chang. 11 (3), 543-551. 
Dee, D.P., Uppala, S.M., Simmons, A.J., Berrisford, P., Poli, P., Kobayashi, S., Andrae, U., Balmaseda, M.A., Balsamo, G., Bauer, P., Bechtold, P., Beljaars, A.C.M., van de Berg, L., Bidlot, J., Bormann, N., Delsol, C., Dragani, R., Fuentes, M., Geer, A.J., Haimberger, L., Healy, S.B., Hersbach, H., Hólm, E.V., Isaksen, L., Kållberg, P., Köhler, M., Matricardi, M., McNally, A.P., Monge-Sanz, B.M., Morcrette, J.-J., Park, B.-K., Peubey, C., de Rosnay, P., Tavolato, C., Thépaut, J.-N., Vitart, F., 2011. The ERA-Interim reanalysis: configuration and performance of the data assimilation system. Q. J. R. Meteorol. Soc. 137, 553-597.

Fischer, E.M., Schär, C., 2010. Consistent geographical patterns of changes in high impact European heatwaves. Nature Geosci.

Forest Europe U. FAO, 2011. State of Europe's forests 2011. Status and trends in sustainable forest management in Europe. In: Ministerial Conference on the Protection of Forests in Europe. pp: 978982.

Ichoku C, Giglio L, Wooster MJ, Remer LA, 2008. Global characterization of biomass-burning patterns using satellite measurements of fire radiative energy. Remote Sensing of Environment 112: 2950-2962.

Parente J, Pereira MG, Tonini M, 2016. Space-time clustering analysis of wildfires: The influence of dataset characteristics, fire prevention policy decisions, weather and climate. Sci Total Environ 559:151-165.

Parente J, Pereira MG, Amraoui M, Tedim F, 2017. Negligent and intentional fires in Portugal: Spatial distribution characterization. Sci Total Environ 624:424-437.

Parente J, Pereira MG, Amraoui M., Tedim, F., 2018a. Negligent and intentional fires in Portugal: Spatial distribution characterization. Science of The Total Environment, 624, 424-437.

Parente J, Pereira MG, Amraoui M., Fischer E.M., 2018b. Heat waves in Portugal: Current regime, changes in future climate and impacts on extreme wildfires. Science of The Total Environment, 631-632, 534-549.

Pereira, M.G., Trigo, R.M., DaCamara, C.C., Pereira, J.M.C., Leite, S.M., 2005. Synoptic patterns associated with large summer forest fires in Portugal. Agric. For. Meteorol. 129, 11-25

Pereira, M.G., Calado, T.J., DaCamara, C.C., Calheiros, T., 2013. Effects of regional climate change on rural fires in Portugal. Clim. Res. 57, 187-200.

San-Miguel-Ayanz, J., Moreno, J.M., Camia, A., 2013. Analysis of large fires in European Mediterranean landscapes: lessons learned and perspectives. For. Ecol. Manag. 294, 11-22.

San-Miguel-Ayanz, J., Durrant, T.H., Boca, R., Libertá, G., Boccacci, F., Di Leo, M., Pérez, J.L., Schulte, E., Benchikha, A., Abbas, M., 2016. Forest Fires in Europe, Middle East and North Africa 2015.

Schmuck, G., San-Miguel-Ayanz, J., Camia, A., Durrant, T., Boca, R., Libertá, G., Schulte, E., 2013. Forest Fires in Europe, Middle East and North Africa 2012. Publications Office of the European Union, Luxembourg.

Trigo, R.M., Pereira, J.M., Pereira, M.G., Mota, B., Calado, M.T., DaCamara, C.C., Santo, F.E., 2006. The exceptional fire season of summer 2003 in Portugal. Int. J. Climatol. 26, 1741-1757.

Trigo, R.M., Sousa, P.M., Pereira, M.G., Rasilla, D., Gouveia, C.M., 2013. Modelling wildfire activity in Iberia with different atmospheric circulation weather types. Int. J. Climatol. 